\title{
The Acceleration of Food Consumption Diversity Policy Implementation through Sustainable Food- Reserved Gardening: The Case of Jakarta
}

\author{
Anisa Febriyanti \\ Faculty of Administrative Science \\ Universitas Indonesia \\ anisafebri93@yahoo.com
}

\author{
Vishnu Juwono \\ Faculty of Administrative Science \\ Universitas Indonesia \\ vjuwono@ui.ac.id
}

\begin{abstract}
This research examines the implementation of the Acceleration of Food Consumption Diversity (P2KP) policy through Sustainable Food-Reserved Gardening (KRPL) in DKI Jakarta. This research applies a post-positivist approach combined with qualitative data collection methods through indepth interviews and desk reviews. The research confirms that the food consumption diversity is not optimal in Jakarta. The one cause is that the private sector has not been included in the process of policy formulation. In addition, the policy design is outdated and unspecified. Furthermore, organizational commitment and inter-organizational coordination need to be improved. Even though there is support from street-level bureaucrats and target groups, the lack of comprehension about policy and passivity of some group members become obstacles in the implementation of the policy. P2KP policy is influenced by socio-economic factors which include knowledge about nutrition, purchasing power, and lifestyle. It can be concluded that the Sustainable Food-Reserved Garden (KRPL) does not support the development of food consumption diversification as a goal of the P2KP policy in DKI Jakarta.
\end{abstract}

Keywords-food diversification; food-reserved gardening; policy implementation.

\section{INTRODUCTION}

Food is a fundamental need, so it plays an important role in the survival of every human being. Therefore, it is the government's responsibility to ensure that the food requirements of the people are fulfilled, not only in terms of quantity, but also the quality of the food. However, rice is still the main source of carbohydrates in the food consumption pattern of the Indonesian people. A comparison between the Indonesian food consumption with the ideal amount can be seen as follows.

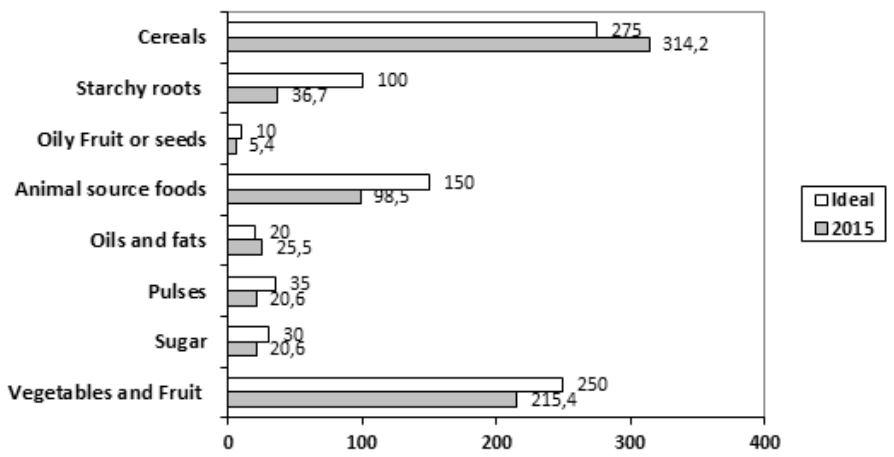

Fig. 1. A Comparison of Food Consumption in 2015 and the Ideal Consumption pattern (gram/cap/day) Source: Food Security Agency, 2016

Figure 1 shows that Indonesian people have exceeded the recommended ideal intake of cereals. In addition to cereals and oils and fats that exceed the ideal amount, none of the other food groups starting from starchy roots to vegetables and fruits have reached the ideal amount. Consumption of food that is not diverse eventually leads to an unbalanced nutrition resulting in a double burden of malnutrition (National Action Plan on Food and Nutrition, 2015). Desirable Dietary Pattern (DDP) scores can be used to observe the quality of food consumption at regional level. The following is a comparison between the actual DDP score and target DDP scores for DKI Jakarta in 2012-2015.

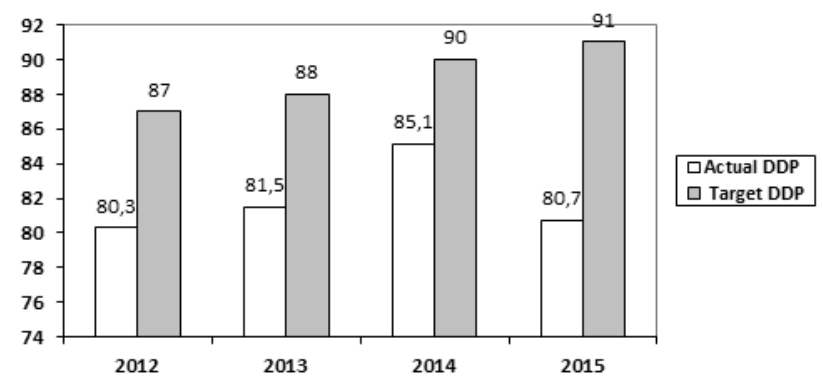

Fig. 2. A comparison of Actual DDP and Target Scores for DKI Jakarta Source: Department of Maritime, Agriculture, and Food Security of DKI Jakarta, 2015 
The data shows that DKI Jakarta has fulfilled and even exceeded the ideal score for the three food groups, namely cereals, animal source foods, and oils and fats. This means that the food intake of the Jakarta residents has reached or even exceeded the ideal score in terms of carbohydrates and proteins. However, their consumption of vitamins and minerals, namely the food group of vegetable and fruit, is still low.

The program pursued in DKI Jakarta to improve and diversify the consumption pattern is the Sustainable FoodReserved Gardening (KRPL). The objective of KRPL listed in the Technical Guidelines for the Acceleration of Food Consumption Diversification (P2KP) is to increase the participation of women groups in the provision of food sources and family nutrition by optimizing the use of gardens. In DKI Jakarta this effort faces problems in determining locations to start KRPLs. Compared to the other provinces in 2015, DKI Jakarta had the densest population.

\begin{tabular}{|c|c|}
\hline Province & Population Density $\left(\right.$ people/ $\left.\mathbf{k m}^{2}\right)$ \\
\hline DKI Jakarta & 15.328 \\
\hline West Jawa & 1.320 \\
\hline Banten & 1.237 \\
\hline DI Yogyakarta & 1.174 \\
\hline Central Jawa & 1.030 \\
\hline
\end{tabular}

Table 1. Population Density of Provinces (2015)

\section{Source: Central Bureau of Statistics, 2016}

The problems faced by KRPL listed in the 2016 Final Report of P2KP are as follows.

1. Lack of socialization, promotion and education of the public about the P2KP program

2. Pests that attack the plants grown

3. Danger of flooding in several locations so greater attention is needed in determining location

4. Expensive production facilities

5. Members of KRPL groups who are not actively involved

6. Group members lacking the knowledge of cultivation

In addition to these problems, the reports of the KRPL Implementation in DKI Jakarta have identified a problem, namely the main constraint faced in the gardens of the members, e.g. the lack of sunlight that stunts the growth of plants.

\section{THEORETICAL REVIEW}

According to Pinstrup-Andersen and Watson II (2011: 29) "Food policy consists in the setting of goals for the food system or its parts, including natural resources, production, processing, marketing, food consumption and safety, and nutrition". To have an impact, a policy should go through an important stage, that is implementation. The definition of implementation is "Implementation of policy is a process of efforts to turn a policy that is still abstract in form into something that is real" (Widodo, 2007: 88). Winter (2012: 258-261) put forward the theory of implementation in the form of "Two sets of variables, namely the process of policy formulation and policy design and the implementation process that is influenced by organizational and inter-organization behavior; street-level bureaucrats; target groups; the socioeconomic context".

The first dimension is policy formulation, as the root of the problem of implementation is often found in this dimension. For example, conflicts that occur in this process create a policy that has ambiguous goals as well as unsuitable causal theories. The second dimension is the policy design. According to Birkland (2015: 231) elements in policy design are namely "the goals of the policy, the causal model, the tools or instruments of the policy, and the targets of the policy". The third dimension is organizational and intergovernmental behavior which can be illustrated through the levels of commitment and coordination. The fourth dimension is the behavior of street-level bureaucrats. According to Poocharoen (2013: 339), "Policies are often very broad and vague due to the complexity of most public policy problems. Thus, during the implementation stage, depending on the level of discretionary power, different bureaucracies have room to interpret policies to fit their own views and maintain practicality. Sometimes, the original intent of the policy, as set by policymakers, is altered due to the bureaucrats' interpretation of the policy". The fifth dimension is the target group that plays an important role in influencing the behavior of street bureaucrats through their response or action. The sixth dimension is the socioeconomic condition. The socioeconomic context forms an important condition in supporting the implementation. The operationalization of the concept of public policy implementation is depicted in the following table:

Table 2. Population Density of Provinces (2015)

\begin{tabular}{|c|c|c|c|}
\hline Concept & Variable & Dimension & Indicator \\
\hline \multirow{6}{*}{$\begin{array}{l}\text { Policy } \\
\text { impleme } \\
\text { ntation }\end{array}$} & \multirow{2}{*}{$\begin{array}{l}\text { Policy } \\
\text { formula } \\
\text { tion and } \\
\text { design }\end{array}$} & $\begin{array}{c}\text { Policy } \\
\text { formulation }\end{array}$ & Conflict level in policy design \\
\hline & & Policy design & $\begin{array}{l}\text { 1. Clarity of policy objectives } \\
\text { 2. Link between problem and } \\
\text { solution } \\
\text { 3. Accuracy of target group } \\
\text { 4. Ability of policy } \\
\text { instruments to encourage } \\
\text { behavior }\end{array}$ \\
\hline & \multirow[t]{4}{*}{$\begin{array}{l}\text { Impleme } \\
\text { ntation } \\
\text { process }\end{array}$} & $\begin{array}{l}\text { Organizationa } \\
1 \text { and inter- } \\
\text { organizational } \\
\text { behavior }\end{array}$ & $\begin{array}{l}\text { 1. Commitment of policy } \\
\text { implementation } \\
\text { 2. Coordination within } \\
\text { organization } \\
\text { 3. Coordination between } \\
\text { organizations } \\
\end{array}$ \\
\hline & & $\begin{array}{l}\text { Behavior of } \\
\text { street-level } \\
\text { bureaucrats }\end{array}$ & $\begin{array}{ll}\text { 1. } & \text { Attitude towards policy } \\
\text { 2. } & \text { Comprehension of policy } \\
\text { 3. } & \begin{array}{l}\text { Attitude towards target } \\
\text { groups }\end{array} \\
\end{array}$ \\
\hline & & Target groups & $\begin{array}{ll}\text { 4. } & \text { Attitude towards policy } \\
\text { 5. Comprehension of policy } \\
\text { 6. } \\
\text { Attitude towards street } \\
\text { bureaucrats }\end{array}$ \\
\hline & & $\begin{array}{l}\text { Socio- } \\
\text { economic } \\
\text { contexts }\end{array}$ & $\begin{array}{l}\text { The influence of socio- } \\
\text { economic factors on policy }\end{array}$ \\
\hline
\end{tabular}

Source: Researcher's Analysis of Data, 2017 


\section{RESEARCH METHODOLOGY}

This research uses a post-positivist approach. This approach employs Winter's public policy implementation theory which suits the research topic. In this approach, the data is collected using an instrument based on the implementation theory so that more focus is placed on factors related to the implementation of the public policy. The theory is formulated into indicators that can help to guide the research process, especially in establishing the interview guidelines and carrying out the analysis. Data collection techniques used in this study are in-depth interviews and literature study. The two techniques are intended to obtain data, both primary and secondary data, and information useful for the research. In addition, data obtained from relevant parties involved in $\mathrm{P} 2 \mathrm{KP}$ policies, such as the government, communities, NGOs, and academia.

\section{RESEARCH RESULTS}

The lack of conflict during policy formulation has resulted in the absence of a policy that has specifically targeted the objectives of food diversification. This multisectoral food policy needs to involve the private sector so that it can provide support in its role as food processor. One of the purposes of the food diversification policy is achieving the ideal DDP score. The vague Implementation objectives of 2016 and 2017 occurred because the legal basis for food diversification has not been updated. Another drawback of the policy design is that the criteria of the specific target to benefit the needy is not stated. Meanwhile, aid in funds and extension that are used as policy instruments have not been able to change people's behavior significantly.

In its implementation in 2017 , there have been delays in the disbursement of funds in the DKI Jakarta and confusion about KRPL funds. Apart from aid funds, there has been no political support in the form of local regulations for food diversification and food security. However, positive support has come from the lower levels, both from extension officers as street-level bureaucrats and the target groups. However, the extension officers need to address the lack of knowledge and lack of activity of the target groups. This policy is influenced by the social and economic context. The decisive social and economic aspects in the food consumption pattern are knowledge, purchasing power, and lifestyle. The urban lifestyles that desire practicality are increasing. This in turn gives rise to increased consumption of prepared foods and beverages. If the community prefers prepared foods, then the vegetables that are easily accessible in the gardens will not have a significant impact. Thus, the activities of Sustainable Food-Reserved Gardening (KRPL) have not been able to support the socialization of food consumption diversification which is one of the objectives of the P2KP policy in DKI Jakarta.

\section{DISCUSSION}

The following is a discussion of the analysis of the dimensions based on the operationalization of Winter's concept of implementation.

\section{1) Policy Formulation Dimensions}

One of the debates that occurred when discussing President Regulation No. 22 of 2009, which is related to the determination of the DDP target which initially was 100 . However, the target was considered to be unrealistic. Finally, a target of 95 was selected. Another debate was related to linking nutritional problems to the National Action Plan on Food and Nutrition (RAN-PG) into food regulations. This occurred because P2KP is included in RAN-PG so that its establishment was intended to solve nutritional problems. The proposed nutritional aspects are already listed in the legal foundations of food diversification. Although it is multisectoral, the formulation of the policy can be said to have involved low levels of conflict. These Low levels of conflict have in turn led to the absence of a policy targeting the objectives of food diversification. Several aspects in the related sectors have not been taken into account in the policy formulation process. For example, seed problems in Indonesia.

In the Technical Guidelines of P2KP 2016, the MP3L program (Local Food Development Model) was aimed at developing the potential of local staple foods to decrease the people's dependence on rice. However, it has only been implemented in three provinces, excluding DKI Jakarta as it does not have local resources. On the other hand, the development of local staple food potentials requires strong marketing and creativity in the processing stage to provide food diversity, not only for those provinces, but also for other provinces to make the impact more widespread. Thus, policy formulation needs to go beyond simply including sectors within the ministry, but should also involve the private sectors that can support food processing.

\section{2) Policy Design Dimensions}

\section{A. Clarity of Policy Purpose}

The objectives of the P2KP policy stated in Presidential Decree 22 of 2009 concerning the Acceleration of Local Resource-Based Food Consumption Diversification Policy can be found in the appendix. The general purpose of the Presidential Regulation stated in the annex to the regulations is to "facilitate and encourage the realization of diverse, balanced and safe nutrition consumption patterns as indicated by a DDP of 95 score by 2015 ". The targeted DDP Scores are found in the preliminary formulation of 2008 and the targeted achievement for 2015. The legal basis has not been updated so that the targeted DDP score implementation in 2016 and 2017 is not clear. The target score of 95 should have been changed in 2016 because it was no longer relevant. The absence of regulatory updates indicates that the policy does not have the necessary political support. 


\section{B. Finding Solutions to the Problems}

According to the Final Report of P2KP DKI Jakarta, the land area of the beneficiaries ranges from a minimum area of 5 $\mathrm{m}^{2}$ to a maximum area of $25 \mathrm{~m}^{2}$. Thus, in Jakarta, the entire KRPL is included in strata 1 with a garden area of $<100 \mathrm{~m}^{2}$ or without a garden. KRPL is constrained in finding a solution to the problem because of the limited land available which makes it difficult to grow any commodities other than vegetables of a limited type.

Table 3. The Population of DKI Jakarta and the Area of KRPL Gardens

\begin{tabular}{|c|c|c|}
\hline City & Population & Garden Area $\left.\mathbf{( m}^{\mathbf{2}}\right)$ \\
\hline Jakarta Selatan & 2.185 .711 & 100 \\
\hline Jakarta Timur & 2.843 .816 & 25 \\
\hline Jakarta Pusat & 914.182 & 45 \\
\hline Jakarta Barat & 2.463 .560 & 80 \\
\hline Jakarta Utara & 1.747 .315 & 61 \\
\hline Total & 10.154 .584 & 311 \\
\hline
\end{tabular}

Source: Central Bureau of Statistics, 2014 and Office of Maritime, Agriculture, and Food Security of DKI Jakarta, 2016

\section{Accuracy of Target Group Selection}

The beneficiaries are a group of people who wish to change their behavior but without specific reference to nutritional criteria. The criteria are still too general and there are no specifications as to who exactly should receive the benefits. In fact, specific conditions can be made by selecting areas using available data, such as areas with high stunting rates, less nutrition or excessive nutrition as priority beneficiaries of the program.

One of the nutritional criteria that can be used is areas with high stunting rates. According to data from the Ministry of Health, stunting or toddlers that are too short for their age due to inadequate nutrition, reached $37.2 \%$ in Indonesia in 2013. The data on stunting is only available for DKI Jakarta and therefore requires further survey. According to WHO, toddlers with stunted growth can become a public health problem if the prevalence is $20 \%$ or more; whereas the percentage for DKI Jakarta is $27.5 \%$ (Ministry of Health, 2016). The basis of evaluation in the Technical Guidelines still leaves a loophole for the rise of conflict of interest. For example, only persons that are known are selected. Therefore, a transparent and objective assessment is required.

\section{The Ability of the Instruments to Encourage Behavior}

One of the instruments used is subsidies in the form of government aid funds. Another instrument used in this policy is information in the form of extension services. Information about food diversification has not been utilized optimally to change the food consumption patterns in the target group. The materials provided are more focused on technical matters relating to crop cultivation.

The instruments have not been able to change the consumption behavior of the community in accordance with the purpose of food diversification. The KRPL activity has not been able to encourage change in community behavior both of the beneficiaries and the community as a whole because the produce of the planted commodities tend to only meet the needs of the beneficiaries. On the other hand, the beneficiaries do not necessarily acquire an awareness of the importance of eating diverse foods.

\section{3) Dimensions of Organizational and Inter-Organization Behavior}

\section{A. Policy Implementation Commitment}

The P2KP Policy has not been implemented with a strong commitment due to the obstacles in the disbursement of funds to the beneficiaries. Unclear information and delays in disbursement of KRPL funds occurred in DKI Jakarta in 2017. Government grants were not yet been received by beneficiaries of KRPL in DKI Jakarta by May of 2017. DKI Jakarta is one of the provinces with $0 \%$ realization of disbursement along with other provinces, namely Aceh, Central Kalimantan, North Maluku, Papua and West Papua; while many other provinces have reached $100 \%$ realization.

DKI Jakarta has no regulation on food diversification or food security in general. With no support either in the form of funds or regulations, this policy has not been widely implemented in other regions due to limited funds. P2KP activities in the center are intended be a pilot concept that can be developed by other regions tailor-made to the specific characteristics of the regions. The regions need to take the initiative to adjust the implementation of $\mathrm{P} 2 \mathrm{KP}$ so that it does not depend on the concept of P2KP from the center which aims at implementation in general.

\section{B. Coordination within Organizations}

Coordination within organizations can be seen in terms of submission of documents when there is a change in positions. Often the submission of documents is delayed for a long time or not submitted at all. It is important for new officials to be more familiar with problems in their field. Without any knowledge of past problems, the new officials in the job must repeat the tasks from the starting point.

This occurred in the Department after a new Head of Food Diversification took the position in 2016. In the framework of this change until May 2017, the documents on the field handled were still not complete. Coordination of good information sharing should be available for officials who are placed in a new position. Coordination within the organization will affect inter-organizational coordination. Difficulties in coordination in the Food Security Agency are faced when new employees occupying this position only have minimal knowledge of food related matters. Information sharing that is not coordinated can result in the ineffectiveness of the implemented program. Developed programs can experience stagnation due to the unavailability of data to be used as material for evaluation to improve the programs that have been already been implemented.

The lack of coordination associated with the exchange of information is likely to reduce the KRPL program into small 
projects that are scattered around with no significant impact on society as a whole. Information can be used to identify deficiencies and aspects that should be maintained in the $\mathrm{P} 2 \mathrm{KP}$ policy. Information is also needed to select the target groups. With information from the nutrition section, the assistance provided for the group will be more beneficial to improve nutrition of the group. Lack or absence of information might cause the program to be implemented in areas that do not need such programs.

\section{Inter-Organizational Coordination}

The Ministry of Agriculture and Food Security, Marine, and Agriculture Agency of DKI Jakarta have a different understanding of the types of grants to be given to the beneficiary groups. Prior to 2016, the P2KP movement was funded by Social Aid funds (Bansos), but starting in 2016 it was funded with Government Assistance (Banper) funds. The Banper Fund requires beneficiaries to provide accountability for goods purchased. Whereas in the Bansos system, the groups receiving money in their group account are allowed to used the funds freely without providing documents related to the purchase of goods.

Food Security, Marine, and Agriculture Agency of DKI Jakarta considered this change in funding as a new name and thus accountability from the beneficiaries. Food Security, Marine, and Agriculture Agency of DKI Jakarta was not the only party who had a different understanding from that of the center. Extension agents also considered that Banper and Bansos were just the same. With such a divergence of understanding, there is the possibility of lax oversight of the use of budgets by lower level executives.

Interagency coordination conducted within the Food Security Agency is not considered to be effective due to the high sectoral ego. Sectoral ego occurs due to the 'low' position of Food Security Agency, which is under the Ministry of Agriculture. The impact is that many parties from other ministries do not feel they have any responsibility to meet the invitation for coordination from the Food Security Agency. Another effect of sectoral ego can be seen in the availability of food in DKI Jakarta. Vegetable commodities need good storage because they are easily damaged. However, in DKI Jakarta no cold storage is available to support the suppy of fresh vegetables. Existing facilities are managed by different institutions making coordination difficult, especially in terms of logistics.

\section{4) The Dimension of Street-Level Bureaucrat Behavior}

\section{A. Attitudes towards Policy}

The policy has the support extension officers who have positive outlook and they feel confident that those policies can benefit society. However, the extension officers are still not fully aware of their duties as part of the government, not just executors who implement the policy according to their own interpretation. Street-level bureaucrats in their routine interaction with the community will influence the kind of policy that is acceptable to the society.

\section{B. Policy Understanding}

Extension officers admitted their lack of understanding related to the $\mathrm{P} 2 \mathrm{KP}$ policy because they did not receive adequate information about the policy. They said that their understanding of extension was more directed at technical matters. In addition, due to the merging of the animal husbandry and agriculture offices, there were extension workers with expertise in animal husbandry who were assigned to provide agricultural extension. In formulating the Activity Plan and Budget Requirement (RKKA), the group is accompanied by an extension officer. The extension officers should provide input if there is a mismatch between the crops selected to be planted and the location available. Thus, the extension officer should have good knowledge of this field.

KRPL is organized through bottom-up planning. The group submits a plan or a request for crops to be planted. Implementation is also based on the planning, and thus the plants will be appropriate for the group and the location and will thus bring benefits for the group. Planning is useful so that crops that have been harvested will not go to waste. This occurred when the groups planted okra plants which were later left to dry. Crops that are abandoned will cause the government aid funds to be ineffective.

\section{Attitudes toward Target Groups}

When there are problems with KRPL, the group members coordinate immediately, as does the extension officer from North Jakarta who claims to have a good relationship with members of the KRPL group. As a matter of fact, this extension officer already knows the members in the group. The proximity between extension officers and the beneficiary group or target group plays an important role in creating cooperation in managing the KRPL. The relationship between the extension worker and group is well established to date. If there is a problem, the extension worker is open to complaints from the group members, especially complaints concerning the implementation of KRPL.

\section{5) Dimension of Target Group Behavior}

\section{A. Attitudes towards Policy}

Target groups generally have a high motivation and desire to gain knowledge. In The policy can still be carried due to the desire of the target groups to increase their knowledge and their penchant of cultivation activities. With a positive attitude towards cultivating crops, the group members become more active in the activities. However, not all members of the group are active due to certain constraints. Some members are only active when they can see direct results.

\section{B. Policy Comprehension}

Comprehension of food diversification has not been the focus of KRPL activities. The materials presented are more of a technical nature usually related to the cultivation of plants. The understanding of the Head of KRPL in North Jakarta on food diversification is still focused on food security and has not yet led to a diverse and balanced nutrition concept. 
Meanwhile, the Chairman of KRPL in South Jakarta believes that food diversity only means having a variety of vegetables. Whereas achieving food diversity requires increased consumption of different types of food other than vegetables. According to the extension officers, the groups lack skills in the use of hydroponic cultivation. Hydroponics technology is one solution to land constraints, especially in urban areas such as DKI Jakarta. However, the knowledge and skills are limited so that planting crops is still mostly done on regular land. The extension officers also found that many crops grown lack sunlight, especially in gardens of the homes of members.

\section{Attitude to Street-Level Bureaucrats}

The good relationship between the extension officers and the group is continued in the coaching activities that take place during group meetings. The head of KRPI South Jakarta is not only involved in formal and routine group meetings, but he can freely report the problems that exist in KRPL to the extension officers outside the meetings. For example, he can discuss various problems, starting from the problem of rat pests to plant fungi.

\section{6) Dimension of Social and Economic Conditions}

In the food consumption pattern, the two significant aspects are knowledge and the purchasing power of the community. Furthermore, the urban lifestyle is also influential. The desire for practicality is increasingly leading to a rise in the consumption of ready-to-eat or prepared foods or beverages. The following is the BPS data on monthly average per capita expenditure on prepared foods and beverages in Jakarta

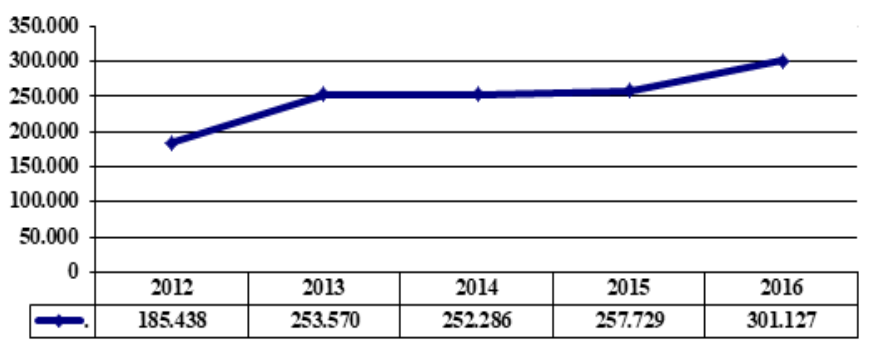

Fig. 3. Average monthly Per Capita Expenditure of Prepared Foods and Beverages in DKI Jakarta 2012-2016

Source: Central Bureau of Statistics, 2012-2016

The data above shows that the consumption of prepared food and beverages increase each year, except in 2014 when it decreased but then increased again reaching a value of $\mathrm{Rp}$ 301,127 in 2016. This means that the people of DKI Jakarta prefer practical food and beverages. Preference tendencies affect food diversification policies. If the community prefers prepared foods, the vegetables that are easily accessible in the yard will not have a significant impact in the community.

\section{CONCLUSION}

From the discussion of policy implementation based on Winter's implementation theory, it can be concluded that the activities of Sustainable Food-Reserved Gardening (KRPL) has not supported the socialization of food consumption which is one of the objectives of the P2KP policy in DKI Jakarta. This can be seen from the aspects of policy implementation, namely the formulation of policies that did not involve the private sector and did not include other aspects, such as problems in the planting areas and seeds. The design of the policy has not yet been updated with regard to the policy objectives and has not been specifically linked to nutritional criteria to provide benefits to the target group. Meanwhile, commitment and coordination within organizations and between organizations still need to be improved. Although the policy received support from street level bureaucrats and target groups, it was hampered by a lack of knowledge and a lack of active members in both extension and cultivation activities. In terms of formulation and implementation, P2KP policies need to take into account social and economic conditions, namely knowledge, purchasing power, and lifestyles of the community, that have an influence on policy.

\section{RECOMMENDATIONS}

Recommendations related to the implementation of the Acceleration of Food Consumption Diversification policy (P2KP) through the activities of Sustainable Food-Reserved Gardening (KRPL) are as follows.

1. The determination of DDP score should be more realistic, based on the ability of the implementers and balanced by the current condition of the community's food consumption pattern. Food policy, which is a multi-sectoral policy, should involve the private sector in food diversification efforts.

2. Legal reform is required in the $\mathrm{P} 2 \mathrm{KP}$ policy, namely it should include Presidential Decree Number 22 of 2009 and Permentan Number 43 of 2009. Observed from a problem and solution perspective, a policy related to vertical diversification in order to increase food consumption is required. More specific criteria for beneficiaries especially nutritional criteria directly related to current problems in food and nutrition should be used.

3. Support from the DKI Jakarta local government is required, both in the form of local regulations and funding. In terms of coordination within the organization, submission of documents to the new person in office should be done immediately. Further, inter-organizational coordination requires an understanding of the situation, such as an understanding of the differences in interpretation of the Banper and Bansos grants provided in order to avoid disagreements.

4. Extension officers of the $\mathrm{P} 2 \mathrm{KP}$ policy require more knowledge about the policy so that they can convey material about food diversification in a better way to the community. In addition, the application of the concept of bottom-up planning should not be ignored to ensure that the cultivated crops do not go to waste.

5. Much more extension materials on food diversification should be provided so that the target group will not only be knowledgeable about technical matters. The role of the KRPL and extension officers is also need to take an active 
[9] Implementation Report of KRPL in DKI Jakarta

role to urge the less active group members to be more motivated to participate in the activities.

6. It is essential for the government to understand the social and economic factors that influence policy. For example, the implementation of the P2KP policy is influenced by the lifestyle of people who prefer food and beverages that are practical. Therefore, cooperation with the private sector, especially the agro-processing sector or food processing, is needed to turn health food commodities that are unattractive and therefore not in demand into attractive and practical packages.

\section{REFERENCES}

[1] Agency for Extension and Development of Human Resources In Agriculture. The number of Civil Servant, THL, and local extension workers

[2] Badan Litbang Pertanian. Kawasan Rumah Pangan Lestari - KRPL. 21 Februari 2017. http://www.litbang.pertanian.go.id/krpl/.

[3] Badan Pusat Statistik. "Pengeluaran Rata-rata Per Kapita Per Bulan Menurut Kelompok Makanan di Provinsi DKI Jakarta (rupiah) 2015". 13 Maret 2017https://jakarta.bps.go.id/linkTabelStatis/view/id/199.

[4] Badan Pusat Statistik. Pengeluaran Untuk Konsumsi Penduduk $\begin{array}{lllll}\text { Indonesia Per } & \text { Provinsi. } & 13 & \text { Maret } & 2017 .\end{array}$ http://bps.go.id/index.php/publikasi/984.

[5] Birkland, Thomas A. (2015). An Introduction to the Policy Process: Theories, Concepts, and Models of Public Policy Making. New York: Routledge.

[6] Decree of the Minister of Agriculture Republic of Indonesia Number $12 / \mathrm{KPTS} / \mathrm{KN} .210 / \mathrm{K} / 02 / 2016$ on the Technical Guideline for the Acceleration of Food Consumption Diversification of 2016

[7] Food Security Agency_. (2016). Directory of Food Consumption Development. Jakarta: Ministry of Agriculture.

[8] Food Security Agency . Strategic Plan for the Food Security Agency 2015-2019. 2015. Retrieved on February 21, 2017. http://bkp.pertanian.go.id/tinymcpuk/gambar/file/Renstra_BKP_20152019_1(1).pdf.
[10] Minister of Agriculture Regulation Number 43 of 2009 on the Acceleration of Food Consumption Diversification Based on Local Resources

[11] Ministry of Health. The situation of toddlers with stunted growth (2016). $14 \quad$ March 2017. http://depkes.go.id/resources/download/pusdatin/infodatin/situasi-balitapendek-2016.pdf.

[12] National Action Plan on Food and Nutrition 2015-2019.

[13] Pinstrup-Andersen, Per, dan Derrill D. Watson II. (2011). Food Policy for Developing Countries: The Role of Government in Global, National, and Local Food Systems. New York: Cornell University Press.

[14] Poocharoen, Ora-orn. (2013). Bureaucracy and the Policy Process. In Araral Jr., Eduardo, et al. (p. 331-342). Handbook of Public Policy. New York: Routledge.

[15] President Reguation Number 22 of 2009 on the Policy of the Acceleration of Food Consumption Diversification Based on Local Resources

[16] The DKI Jakarta Office for Maritime, Agriculture and Food Security. 2016 Final Report of P2KP Dinas Kelautan, Pertanian, dan Ketahanan Pangan DKI Jakarta

[17] Widodo, Joko. (2007). Analisis Kebijakan Publik: Konsep dan Aplikasi Analisis Proses Kebijakan Publik. Malang: IKAPI.

[18] Winter, Soren. (2012). Implementation. In B. Guy Peters \& Jon Pierre (Ed.). The SAGE Handbook of Public Administration (p. 255-261). London: SAGE Publications.

\section{SHORT BIOGRAPHY}

Anisa Febriyanti is an research assistant in the Collaborative Governance and Dynamic Public Services (CGDPS) research cluster at the Faculty of Administrative Science, Universitas Indonesia.

Vishnu Juwono is a lecturer in public administration and researcher in the Collaborative Governance and Dynamic Public Services (CG-DPS) research cluster at the Faculty of Administrative Science, Universitas Indonesia 